\title{
LIFE SAFETY
}

\section{THE ASSESSMENT OF LABOR CONDITIONS ACCORDING TO HAZARD INDICATORS ON THE BASIS OF PRODUCTION RISK DETERMINATION}

\author{
${ }^{1}$ Professor Tretyakov Oleg, \\ ${ }^{2}$ Assistant Professor Harmash Bohdan, \\ ${ }^{3}$ Postgraduate Student, Yevheniia Biletska
}

\author{
Ukraine, Kharkiv, Ukrainian State University of Railway Transport; \\ ${ }^{1}$ Professor of the Department of Human Engineering and Environmental Protection; \\ ${ }^{2}$ Assistant Professor of the Department of Human Engineering and Environmental Protection; \\ ${ }^{3}$ Postgraduate Student of the Department of Human Engineering and Environmental Protection
}

DOI: https://doi.org/10.31435/rsglobal_ws/31012020/6901

\section{ARTICLE INFO}

Received: 21 November 2019

Accepted: 19 January 2020

Published: 31 January 2020

\section{KEYWORDS}

transport,

occupational risk

industrial risk,

hazardous factor,

occupational safety and

health, occupational safety,

hygiene standard.

\begin{abstract}
The article deals with the principles, methods and criteria of risk assessment to create controlled conditions that minimize the potential consequences of harmful and hazardous factors in the production environment and the labour process of workers in the transportation industry. There has been conducted the analysis of methods of determining the level of danger from the combined effect of harmful factors in the production conditions that currently exist in Ukraine, their shortcomings are identified and the ways to solve them are proposed. A unified approach to the calculation of production risk depending on the parameters of the working area is proposed taking into account the time spent by hazardous factors working in the affected area, which does not require entering multiple scales to characterize the quality of the environment. Based on the algorithm for converting environmental parameters into an indicator of production risk, an analysis of working conditions maps is carried out, the subjectivity of assessing the actual conditions and nature of work in Ukraine is proved. It has been revealed that the obtained indicators of integral risk testify to the contradictions of the Ukrainian legislation to the world standards for the protection of health and safety at work.
\end{abstract}

Citation: Tretyakov Oleg, Harmash Bohdan, Yevheniia Biletska. (2020) The Assessment of Labor Conditions According to Hazard Indicators on the Basis of Production Risk Determination. World Science. 1(53), Vol.2. doi: 10.31435/rsglobal_ws/31012020/6901

Copyright: (C) 2020 Tretyakov Oleg, Harmash Bohdan, Yevheniia Biletska. This is an open-access article distributed under the terms of the Creative Commons Attribution License (CC BY). The use, distribution or reproduction in other forums is permitted, provided the original author(s) or licensor are credited and that the original publication in this journal is cited, in accordance with accepted academic practice. No use, distribution or reproduction is permitted which does not comply with these terms.

Introduction. Being integrated into the world community, the development and implementation of the basic provisions of harmonizing the principles, methods and criteria for assessing the risk to workers' health with international approaches are a necessary condition for ensuring the socio-economic development of the state [1]. In the documents of the European Commission it is emphasized that a scientifically based risk assessment plays an exceptional role in the preparation and improvement of legislation in the field of protecting the rights of citizens and especially their health $[3,4]$. There is a separate provision that conducting a risk assessment in accordance with internationally recognized procedures gives grounds for judicial protection of citizens' own rights [2]. 
Also, it is necessary to pay attention to the fact that in the English-speaking conceptual system, hazards imply both dangerous and harmful production factors [3].

Labor protection is one of the most important tasks of the socio-economic policy of the state, as well as the individual enterprise and organization. However, measures to improve working conditions to prevent occupational injuries and occupational diseases in modern production conditions of Ukraine have proved ineffective.

It is necessary to provide a comprehensive analysis of working conditions, as well as the creation of a safety management subsystem based on design approaches in a common production management system [5]. There are also many factors in the production environment that require the determination of an integral indicator of the level of danger to workers in the production environment. The theoretical basis for the formation of a new concept of security in organizational and technical systems can be used axiom of the potential danger, the Weber-Fechner law, the Liebig minimum principle, the Shelford tolerance law, the Farmer principle [6]. To determine the risk of reducing life expectancy when exposed to harmful factors in the working area of enterprises, it is permissible to take the Weber-Fechner law [6].

The purpose of the research is to develop the method of determining the level of danger for workers in the working area under the condition of the combined action of harmful factors of different classes on the basis of an integral indicator - production risk

Research results: the object of hazard analysis is the system "man - machine - environment", and it combines technical objects, people and the environment that interact with each other. Potential danger or harmfulness of production processes means the presence of dangerous and harmful factors that while acting on a person can lead to work-related injury or occupational disease.

Existing methods for determining the level of danger from the combined action of harmful factors in production conditions are based on the principle of the Liebig minimum, but its drawback is the consideration of factors that have the maximum effect [6,7]. But there are other factors that do not have overdone of acceptable standards, although they also significantly affect the health status of employees. Such a contradiction can be eliminated by introducing probabilistic estimates of the hazard level of the working environment. It is proposed to determine the level of danger in the working area using the risk function, which will automate the certification process of jobs [8].

The form of expression of theoretical risk is a statistical indicator, reduced to the probability of some undesirable event. In the future, the probability of such an event, some estimate of the expected harm is combined into one indicator, and therefore a combination of risk and harm or a reward set is combined. In statistical decision theory, the risk function $\delta(x)$ for the parameter $\theta$, calculated for some observable parameters $x$, is defined as the mathematical expectation of the loss function $L(\theta, \delta(x))$ :

$$
R(\theta)=\int L(\theta, \delta(x)) \cdot f(x \mid \theta) d x,
$$

where $L(\theta, \delta(x))$ - the loss function of the estimation parameter $\theta$ and the estimation value $\delta(\mathrm{x})$;

$f(x \mid \theta)$ - the probability of an unwanted event.

Risk assessment in the working area under the influence of environmental factors is generally performed with the assumption that the level of contamination is known [9]. This means that the contamination event has already occurred, i.e $P=1$.

Usually, for the loss function $L(\theta, \delta(x))$, some cost unit of risk is taken that characterizes the consequences of an event. From the perspective of the employer, the cost measure of risk will be taken to be equal to the amount of five years' earnings of the employee, in accordance with the law. Establishing such a cost estimate may be appropriate for other levels of severity of adverse events.

According to the Weber-Fechner law, in the case of atmospheric air pollution in the general case, there is a functional dependence on the level of pollution, sensation and risk:

$$
r=1 / k \cdot \lg C / C_{0},
$$

where $r$-the level of risk;

$C$ - concentration of harmful substances in the air, $\mathrm{mg} / \mathrm{m}^{3}$;

$k$-the proportionality factor;

$C_{0}$-the lowest concentration at which action is felt. 
Taking into account the normative parameters determined experimentally for each substance, two fixed points of dependence can be established (3). Substitute $1 / k$ for $\lambda$ to simplify the transformations:

ГДК (permissible exposure limit)

ЛК (lethal concentration)

$$
\left\{\begin{array}{l}
1 \cdot 10^{-6}=\lambda \cdot \lg \text { ГДК }{ }_{\text {Сд }} / \mathrm{C}_{0} \\
0,5=\lambda \cdot \lg Л \mathrm{~K}_{50} / \mathrm{C}_{0} \\
\mathrm{r}=\lambda \cdot \lg C / C_{0} .
\end{array}\right.
$$

Solving the system of equations (4) for concentrations of pollutants that exceed ГДК (permissible exposure limit) will be as follows:

$$
r=\left(0,5-1 \cdot 10^{-6}\right) / \lg \left(Л \kappa_{50} / \Gamma Д К_{\text {сд }}\right) \cdot \lg \left(\mathrm{C} / Г Д К_{\text {Сд }}\right)+1 \cdot 10^{-6} .
$$

Similarly, we determine the risk dependencies for noise, ionizing radiation and electromagnetic oscillations to calculate the potential risk when different factors are involved (Table 1).

\begin{tabular}{|c|c|c|c|c|}
\hline $\begin{array}{c}\text { quality } \\
\text { environment } \\
\text { parameters }\end{array}$ & $\begin{array}{c}\text { Units of } \\
\text { measurement }\end{array}$ & $\begin{array}{l}\text { Acceptable level } \\
\text { standard }\end{array}$ & Harmful level & $\begin{array}{l}\text { Formula } \\
\text { to calculate the risk }\end{array}$ \\
\hline $\begin{array}{l}\text { Chemical } \\
\text { substances }\end{array}$ & $\mathrm{mg} / \mathrm{m}^{3}$ & $\begin{array}{l}\Gamma Д К_{\text {сд }} \\
\text { depends on the } \\
\text { substance }\end{array}$ & $\pi_{50}$ & $r=10^{-6}+b \cdot \lg \frac{C}{\Gamma Д К}$ \\
\hline Noise & $\mathrm{dBA}$ & ГДР & $130 \mathrm{dBA}$ & $r=10^{-6}+0,038 \cdot \lg \frac{I}{I_{0}}$ \\
\hline $\begin{array}{l}\text { Ionizing } \\
\text { radiation }\end{array}$ & m3 per year ${ }^{-1}$ & $\begin{array}{l}\text { Dose limit } \\
\text { ГДР }=20\end{array}$ & $>50$ & $r=10^{-6}+0,358 \cdot \lg \frac{D_{E}}{\Gamma Д Р}$ \\
\hline $\begin{array}{l}\text { Electromagnetic } \\
\text { fluctuation }\end{array}$ & $\mathrm{W} / \mathrm{m}^{2}$ & $\begin{array}{c}\text { ГДЕЕ, } \\
\text { depends on } \\
\text { frequency }\end{array}$ & $>500$ & $r=10^{-6}+k \cdot \lg \frac{E}{\Gamma Д E E}$ \\
\hline
\end{tabular}

Table 1. The calculation of the potential risk under the influence of heterogeneous factors

ГДК (permissible exposure limit)

ГДР (alarm level)

ЛК (lethal concentration)

ГДЕЕ (maximum permissible energy load)

When assessing the level of danger, the main action is to convert information about any property of environmental parameters into the risk indicators. But at this stage there is a complexity, which is due to the fact that previous studies of the nature of the action of harmful substances and other factors were conducted without taking into account the mutual influence of factors. Therefore, the question of dose-effect transformation should be solved on the basis of the available experimental data in Table. 1. Thus, the specified transformation can be carried out with respect to each elementary property, with the subsequent reduction of individual indicators to a single criterion of quality of the system as a whole. But in the general case, considering the nature of causation in the sequence "action - feeling - reaction", this is of no fundamental importance.

Further, the total risk in such a sequence is calculated. First, the values of the annual risk for each factor $r_{i}$, are calculated, and then the value of the integral risk is calculated:

$$
R=1-\prod_{1=1}^{n}\left(1-r_{i}\right),
$$

Therefore, all of the above indicates a unified approach to calculating the estimation of the parameters of the working area, which does not require the introduction of multiple scales to characterize the quality of the environment. In general, using the estimate as a ratio of two quantities is equivalent to the transition from intensity to extensive impact characteristics. It is also known that the dose is an integral value and is determined based on the time of action. The dependencies obtained in the application for job certification greatly facilitate the assessment of factors of the production 
environment and the working process. Also, taking into account the mutual influence of factors, it is possible to determine the priority of occupational safety measures, taking into account the level of production and occupational risks, and refining recommendations for improving working conditions.

Although this approach cannot be regarded as absolutely correct because it does not take into account the probability of a worker working in the area of the hazard factor $\boldsymbol{i}$. Given this, the probability of the presence of the hazard factor $i$ in the working area can be determined by the following formula:

$$
P_{v_{i}}=P_{i}^{v} \cdot P_{i}^{p},
$$

where $P_{i}^{v}$-the probability of action of the dangerous factor $i$;

$P_{l}^{p}$ - the probability of a worker's presence in the area of the hazard factor $i$.

Also, the probability of action of the dangerous factor $i$; and the probability of a worker's presence in the area of its action is determined by the following formulas:

$$
P_{i}^{v}=t_{i}^{v} / T_{C M} \text { i } P_{i}^{p}=t_{i}^{p} / T_{C M},
$$

where $t_{i}^{v}$-the stay period of the dangerous factor $i$

$t_{t}^{p}$ - the stay period of an employee in the area of the hazard factor $i$.

$T_{C M}$ - the stay period of the change.

Substituting these expressions into the following formula (7), we obtain the probability of the hazard factor $\boldsymbol{i}$. on the worker:

$$
P_{v_{i}}=\frac{1}{T_{C M}^{2}}\left(t_{i}^{v} \cdot t_{i}^{p}\right) .
$$

In the presence of $2,3, \ldots \mathrm{n}$ harmful factors, the probability of their action is determined as follows:

$$
\begin{aligned}
& P_{v}(2)=P_{v_{2}}+P_{v_{1}}-P_{v_{2}} \cdot P_{v_{1}} \\
& P_{v}(3)=P_{v_{3}}+P_{v_{2}}-P_{v_{3}} \cdot P_{v_{2}} \\
& P_{v}(n)=P_{v_{n}}+P_{v_{n-1}}-P_{v_{n}} \cdot P_{v_{n-1}}
\end{aligned} .
$$

Provided that the probability of the effects of harmful factors on workers is known, then the determination of the harmfulness of the production process as a whole will proceed as follows:

$$
P_{n n}^{0}=\frac{N_{1} P_{0}(1)+N_{2} P_{0}(2)+\ldots+N_{n} P_{0}(n)}{N},
$$

where $N_{1}, N_{2}, \ldots N_{n}$ - the number of the employees covered by the action of $1,2,3, \ldots \mathrm{n}$ hazard factors;

$P_{0}(1), P_{0}(2), \ldots P_{0}(n)$ - the probability of the action on the employees of $1,2,3, \ldots \mathrm{n}$ hazard factors;

$N$ - the total amount of workers

The probability of action of the dangerous factor $i$.can be determined by the following formula:

$$
P_{b_{j}}=P_{j}^{b} \cdot P_{j}^{p} \cdot P_{j}^{n c},
$$

where $P_{j}^{b}$ - the probability of the presence in the working area of the dangerous factor $\boldsymbol{i}$ (substance);

$P_{j}^{p}$ - the probability of a person being in the area of action of the dangerous factor $\boldsymbol{i}$ (substance);

$P_{j}^{n c}$-the amazing ability of the dangerous factor $\boldsymbol{i}$ (substance).

The probability of the presence in the working area of the hazard factor $\boldsymbol{i}$ (substance) and the probability of a person being in the area of action of this factor is determined by the formula (8). And the impressive ability of the dangerous factor $\boldsymbol{i}$ (substance) is defined as:

$$
P_{j}^{n c}=\frac{d_{j}}{D_{j}},
$$

$d_{j}-$ the actual level (content) of the dangerous factor $\boldsymbol{j}$ (substance);

$D_{j}$ - the limit level (content) of the dangerous factor $\boldsymbol{j}$ (substance).

The limit level (content) of the dangerous factor $j$ (substance) is one in which workers are subject to the fastest evacuation from the danger zone.

Substituting into (12) the expressions for $P_{j}^{b}, P_{j}^{p}$ and $P_{j}^{n c}$, we obtain:

$$
P_{b_{j}}=\frac{t_{j}^{b} \cdot t_{j}^{p} \cdot d_{j}}{T_{C M}^{2} \cdot D_{j}} .
$$


The probability of harmful effects of $m$ factors is determined by the following formula:

$$
P_{b}(m)=1-\prod_{j=1}^{m}\left(1-P_{b_{j}}\right) .
$$

On the basis of the algorithm of transformation of the environmental parameters into an indicator of an industrial risk, the map analysis of working conditions was carried out according to the results of the certification of the jobs of the regional railway branch of the Southern Railway PJSC Ukrainian Railway. The data obtained is shown in Table 2.

ГДК (permissible exposure limit)

ГДР (alarm level)

Table 2. The calculation of the evaluation of the working area parameters

\begin{tabular}{|c|c|c|c|c|c|c|c|}
\hline No. & $\begin{array}{l}\text { Workplace, } \\
\text { profession, } \\
\text { workshop } \\
\text { (section, } \\
\text { department) }\end{array}$ & $\begin{array}{l}\text { Class of } \\
\text { working } \\
\text { conditions }\end{array}$ & $\begin{array}{c}\text { Factors of } \\
\text { production } \\
\text { environment and } \\
\text { working process }\end{array}$ & $\begin{array}{l}\text { Standard } \\
\text { value } \\
\text { (ГДК), } \\
\text { (ГДР) }\end{array}$ & $\begin{array}{l}\text { Actual } \\
\text { value }\end{array}$ & $\begin{array}{l}\text { Potential } \\
\text { risk, } \\
\quad r_{i}\end{array}$ & $\begin{array}{l}\text { Integral } \\
\text { risk, } \\
\quad R\end{array}$ \\
\hline \multirow[t]{3}{*}{1} & \multirow{3}{*}{$\begin{array}{l}\text { Electric gas } \\
\text { cooker, } \\
\text { mechanical } \\
\text { workshops } \\
\text { (premises) }\end{array}$} & \multirow[t]{3}{*}{3.1} & $\begin{array}{l}\text { Hazardous } \\
\text { chemicals, } \\
\text { (Manganese) }\end{array}$ & 0,2 & 0,31 & 0,02164 & \multirow{3}{*}{0,204081} \\
\hline & & & $\begin{array}{l}\text { Dust of fibrogenic } \\
\text { action } \\
\text { (iron oxide) }\end{array}$ & 6 & 6,5 & 0,004434 & \\
\hline & & & $\begin{array}{l}\text { Infrared radiation, } \\
\mathrm{W} / \mathrm{m}^{2}\end{array}$ & до 140 & 223 & 0,182853 & \\
\hline \multirow[t]{3}{*}{2} & \multirow{3}{*}{$\begin{array}{l}\text { Electric gas } \\
\text { cooker, } \\
\text { mechanical } \\
\text { workshops } \\
\text { (out- of- } \\
\text { doors) }\end{array}$} & \multirow[t]{3}{*}{3.1} & $\begin{array}{l}\text { Hazardous } \\
\text { chemicals, } \\
\text { manganese }\end{array}$ & 0,2 & 0,33 & 0,024727 & \multirow{3}{*}{0,223607} \\
\hline & & & $\begin{array}{c}\text { Dust of fibrogenic } \\
\text { action } \\
\text { (iron oxide) }\end{array}$ & 6 & 6,3 & 0,002703 & \\
\hline & & & $\begin{array}{l}\text { Infrared radiation, } \\
\mathrm{W} / \mathrm{m}^{2}\end{array}$ & до 140 & 234 & 0,201765 & \\
\hline 3 & $\begin{array}{c}\text { Machinist of } \\
\text { fixed rail car } \\
1 \mathrm{~A} \\
\text { mechanical } \\
\text { workshops } \\
\end{array}$ & 3.2 & Noise, dBA & 80 & 83 & 0,000609 & 0,000609 \\
\hline \multirow[t]{2}{*}{4} & \multirow[b]{2}{*}{$\begin{array}{l}\text { Blacksmith of } \\
\text { manual forging, } \\
\text { workshop of } \\
\text { mechanical } \\
\text { workshops, } \\
\text { forge }\end{array}$} & \multirow[t]{2}{*}{3.3} & Noise, dBA & 75 & 92 & 0,003373 & \multirow[b]{2}{*}{0,326984} \\
\hline & & & $\begin{array}{l}\text { Infrared radiation, } \\
\qquad \mathrm{W} / \mathrm{m}^{2}\end{array}$ & till 140 & 320 & 0,324706 & \\
\hline \multirow[t]{2}{*}{5} & \multirow{2}{*}{$\begin{array}{l}\text { Tractor driver, } \\
\text { mechanical } \\
\text { workshops }\end{array}$} & \multirow[t]{2}{*}{3.2} & $\begin{array}{l}\text { Dust of fibrogenic } \\
\text { action }\end{array}$ & 4 & 4,3 & 0,003834 & \multirow[t]{2}{*}{0,005402} \\
\hline & & & Noise, $\mathrm{dBA}$ & 80 & 88 & 0,001574 & \\
\hline 6 & $\begin{array}{l}\text { Machinist of } \\
\text { the railway } \\
\text { construction } \\
\text { machine, } \\
\text { mechanical } \\
\text { workshops }\end{array}$ & 3.2 & Noise, dBA & 80 & 85 & 0,001001 & 0,001001 \\
\hline
\end{tabular}

The conducted assessment of working conditions shows that workplaces № 1, № 2, № 4 belong to 3.1 class according to [10], but the integral risk indicators according to [4] are excessive. Workplaces № 3, № 5, № 6 belong to 3.2 class, where the calculations of integral risk indicators are $10^{-4}, 10^{-3}$ i $10^{-3}$ respectively, that is, the maximum permissible and higher [4]. So, we have a proven 
subjectivity to evaluate the actual conditions and the nature of work according to [10]. Integral risk indicators testify to the contradiction of Ukrainian legislation with the world health and safety standards to create controlled conditions that minimize the potential consequences of harmful and hazardous factors in the production environment and the working process [3].

Conclusions. The question as to the application of methods of determining the level of hazard from the combined effects of harmful factors in production conditions has been considered. As a result of the conducted researches it has been determined that the disadvantage of the existing approach to job certification in our country is the neglect of the effect of mutual influence of factors. Other factors that do not exceed allowances, but which have a significant impact on the health of employees, are also disregarded.

As a result, the feasibility of using a method of determining the level of hazard for workers in the working area based on the dose-effect transformation was substantiated. There has been obtained a new approach to the calculation of the estimating the parameters of the working area, which does not require the introduction of multiple scales to characterize the quality of the environment. The contradiction of part of the Ukrainian legislation with the world standards on health and safety has been revealed.

\section{REFERENCES}

1. Human Health Risk Assessment Toolkit: Chemical Hazards. Harmonization Project Document. IPCS, WHO, 2010. № 8. 105 p. URL: https://apps.who.int/iris/handle/10665/44458 (last access: 7.12.2019).

2. Consumer Health and Food Safety. COM (97) 183 final. Communication of the EU, 1997. 35 p. URL: https://ec.europa.eu/commission/presscorner/detail/en/IP_97_508 (last access: 21.01.2020).

3. ISO 45001 Системи менеджменту охорони здоров`я і безпеки праці. Вимоги з застосування. URL: https://www.iso.org/standard/63787.html (дата звернення 22.01.2020).

4. ISO 31000 Risk management. Principles and guidelines. URL: https://risk-engineering.org/ISO-31000-riskmanagement/ (last access: 20.01.2020).

5. Про охорону праці: Закон України від 18 лист. 2012 p. URL: http://zakon4.rada.gov.ua/laws/show/2694-12 (дата звернення 25.01.2020).

6. Гогунский, В.Д., Руденко С.В., Урядникова И.В.Теория и практика оценки риска здоровью от воздействия факторов внешней среды. Безпека життя $і$ діяльності людини - освіта, наука, практика: зб. наук. пр. Х міжнар. наук.-метод. конф. Київ : Центр учбової літератури, 2011. С. 170-175.

7. ДСТУ ISO 14001:2006. Системи екологічного керування. Вимоги та настанови щодо застосування (ISO 14001:2004, IDT). [Чинний від 2016-07-01]. Київ, 2006. 17 с. (Держспоживстандарт України).

8. Басиль Е.Е., Изотов С.А., Гогунский В.Д. Риск сокращения продолжительности жизни: рабочая зона. Труды Одесского политехнического университета. 1997. Вып. 2. С.133-135.

9. Руденко, С.В., Гогунский В.Д. Оценка экологической безопасности в проектах: монографія. Одесса : Феникс, 2006. 144 с.

10. Про затвердження Державних санітарних норм та правил «Гігієнічна класифікація праці за показниками шкідливості та небезпечності факторів виробничого середовища, важкості та напруженості трудового процесу» / Наказ МО3 України № 248 від 08 квіт. 2014 p. URL: https://zakon2.rada.gov.ua/laws/show/z0472-14 (дата звернення 21.01.2020). 